\title{
Factors affecting organizational commitment of employee's of Lao development bank
}

\begin{abstract}
This study was conducted in Vientiane Capital, Lao PDR to investigate the factors affecting organizational commitment and the level of the organizational commitment of employees of Lao Development Bank. The study sampled 196 employees using Yamane's sampling technique. The data was collected through a structured questionnaire and Stata version 23 was used as an analysis tool. The overall picture of the study found that the level of the organizational commitment of employees of Lao Development Bank was at high level. The aspects considered, from highest to lowest mean level, were continuance, followed by normative and affective commitment, respectively.
\end{abstract}

Keywords: factors, employee commitment, Lao development bank
Special Issue - 2018

Phanthasack Visanh, Huaifu Xu

China Pharmaceutical University, China

Correspondence: Phanthasack Visanh, Master Candidate in Business Management, School of International Pharmaceutical Business, China Pharmaceutical University, No.639, Longmian Road Nanjing, Jiangsu, province, China, 2 I I 198, Tel +86 15895835763,Email Cuteboy_9999@hotmail.com

Received: April 30, 2018 | Published: December 31, 2018

\section{Introduction}

Background of the study: An organization's success needs to rely on several important factors and the employee's commitment to organization is a fundamental factor, which will help the organization achieve its desired goals and increase organizational efficiency and effectiveness. Employee commitment is, nowadays, considered one of the most important elements in human resource management, and it has been shown that employee commitment is linked mostly to work values, work motivation and work involvement. ${ }^{1-2}$

Employee commitment could be measured and defined as an employee's level of identification and involvement in the organization. ${ }^{3}$ General issues concerning the factors affecting employee commitment have been explored previously and have shown that demographic factors such as age, gender, marital status, education level and length of employment were related to employee commitment.-5 However, these studies also have found that job satisfaction and development opportunities were strongly related to affective employee commitment. Indeed, some studies also found other variables that affect organizational commitment included emotional intelligence $^{6}$ and occupational stress. ${ }^{7}$ To date, Meyer and Allen's ${ }^{8}$ (a three-component model of organizational commitment affective, continuance and normative commitment) can be regarded as a dominant model in organizational commitment research. ${ }^{9}$

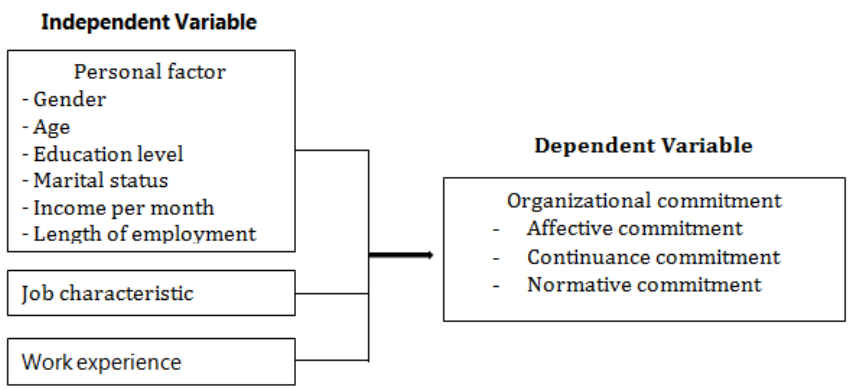

Figure I The model of three types of variables affecting organizational commitment.

Source: Steers, R. M. $1977^{10}$
Lao Development Bank (LDB) is 100\% owned by Lao government, operating under the supervision of the Bank of Lao PDR. LDB has actively contributed to the implementation of the state/party's policies and guidelines, based on its rights and roles, in order to stimulate the national social-economic development. Nevertheless, to compare with other private banks, LDB still has low operating efficiency. Therefore, investigating the level of organizational commitment of employees of Lao Development Bank and finding the factors that affect employee commitment will help to develop organizational policies, which gear towards the improvement of employee commitment. Thus, improvement of employee commitment is a potential way to improve operating efficiency.

\section{Methodology}

The study has sampled 196 employees using Yamane's sampling technique. The samples were chosen from headquarters and the Vientiane capital branch of Lao Development Bank. The primary data was collected using a structured self-made questionnaire. The questionnaire consisted of four sections: Section 1: demographic information of respondents, Section 2: job characteristics, Section 3: work experiences and Section 4: organizational commitment. At the end of the questionnaire, the researcher provided open-ended questions which were used to attain more opinions and suggestions about organizational commitment from the respondents. The questionnaire was constructed based on Likert's five-point scale: strongly disagree, disagree, moderate, agree and strongly agree, that carried the values of 1, 2, 3, 4 and 5 respectively. The researcher used frequency and percentage methods to analyze profiles of the respondents. The researcher used mean and standard deviation to analyze the level of employee commitment of Lao Development Bank. The independent t-test for two groups of variables and F-test, used one-way ANOVA (Analysis of Variance) for testing hypotheses, which had variables of more than two groups. When differences were found, the researcher conducted the multiple comparison of LSD test (Least-Significant Difference) to find out which pairs were different, and the Pearson Product-Moment Correlation Coefficient was also employed in the research to find the relationship between independent variables and dependent variables of organizational commitment. The interpretation 
of mean and standard deviation of the level of agreement concerning organizational commitment was based on this criterion. ${ }^{11}$

\section{Results}

The first part of the questionnaire sought the demographic information of respondents classified by gender, age, educational level, marital status, income per month and length of employment. A total of 196 respondents were calculated by using frequency and percentage. All information is displayed in Table 1-6 as follows:

Table I Demographic information of respondents classified by gender

\begin{tabular}{lllll}
\hline Gender & Frequency & Percent & $\begin{array}{l}\text { Valid } \\
\text { Percent }\end{array}$ & $\begin{array}{l}\text { Cumulative } \\
\text { Percent }\end{array}$ \\
\hline Male & 94 & 48.0 & 48.0 & 48.0 \\
Female & 102 & 52.0 & 52.0 & 100.0 \\
Total & 196 & 100.0 & 100.0 &
\end{tabular}

Table 2 Demographic information of respondents classified by age

\begin{tabular}{lllll}
\hline Age & Frequency & Percent & $\begin{array}{l}\text { Valid } \\
\text { Percent }\end{array}$ & $\begin{array}{l}\text { Cumulative } \\
\text { Percent }\end{array}$ \\
\hline 20-30 years & 26 & 13.3 & 13.3 & 13.3 \\
$31-40$ years & 97 & 49.5 & 49.5 & 62.8 \\
41-50 years & 53 & 27.0 & 27.0 & 89.8 \\
Above 50 years & 20 & 10.2 & 10.2 & 100.0 \\
Total & 196 & 100.0 & 100.0 & \\
\hline
\end{tabular}

Table 3 Demographic information of respondents classified by education Level

\begin{tabular}{lllll}
\hline Education Level & Frequency & Percent & $\begin{array}{l}\text { Valid } \\
\text { Percent }\end{array}$ & $\begin{array}{l}\text { Cumulative } \\
\text { Percent }\end{array}$ \\
\hline $\begin{array}{l}\text { Below than Bachelor's } \\
\text { degree }\end{array}$ & 5 & 2.6 & 2.6 & 2.6 \\
Bachelor's degree & 100 & 51.0 & 51.0 & 53.6 \\
Master's degree & 75 & 38.3 & 38.3 & 91.8 \\
Doctor's degree & 16 & 8.2 & 8.2 & 100.0 \\
Total & 196 & 100.0 & 100.0 & \\
\hline
\end{tabular}

Table 4 Demographic information of respondents classified by marital status

\begin{tabular}{lllll}
\hline $\begin{array}{l}\text { Marital } \\
\text { status }\end{array}$ & Frequency & Percent & $\begin{array}{l}\text { Valid } \\
\text { Percent }\end{array}$ & $\begin{array}{l}\text { Cumulative } \\
\text { Percent }\end{array}$ \\
\hline Single & 62 & 31.6 & 31.6 & 31.6 \\
Married & 112 & 57.1 & 57.1 & 88.8 \\
Divorce & 22 & 11.2 & 11.2 & 100.0 \\
Total & 196 & 100.0 & 100.0 &
\end{tabular}

Table 5 Demographic information of respondents classified by Income per month

\begin{tabular}{lllll}
\hline Income per month & \multicolumn{2}{l}{ Frequency Percent } & $\begin{array}{l}\text { Valid } \\
\text { Percent }\end{array}$ & $\begin{array}{l}\text { Cumulative } \\
\text { Percent }\end{array}$ \\
\hline Below 2.000.000 kip & 11 & 5.6 & 5.6 & 5.6 \\
$2.000 .001-5.000 .000$ kip & 92 & 46.9 & 46.9 & 52.6 \\
$5.000 .001-10.000 .000$ kip & 59 & 30.1 & 30.1 & 82.7
\end{tabular}

$\begin{array}{lllll}\text { Above 10.000.000 kip } & 34 & 17.3 & 17.3 & 100.0 \\ \text { Total } & 196 & 100.0 & 100.0 & \end{array}$

Table 6 Demographic information of respondents classified by length of employment

\begin{tabular}{lllll}
\hline $\begin{array}{l}\text { Length of } \\
\text { employment }\end{array}$ & Frequency & Percent & $\begin{array}{l}\text { Valid } \\
\text { Percent }\end{array}$ & $\begin{array}{l}\text { Cumulative } \\
\text { Percent }\end{array}$ \\
\hline Below I year & 12 & 6.1 & 6.1 & 6.1 \\
I-5 years & 57 & 29.1 & 29.1 & 35.2 \\
6-10 years & 61 & 31.1 & 31.1 & 66.3 \\
II-15 years & 36 & 18.4 & 18.4 & 84.7 \\
I6-20 years & 15 & 7.7 & 7.7 & 92.3 \\
Above 20 years & 15 & 7.7 & 7.7 & 100.0 \\
Total & 196 & 100.0 & 100.0 & \\
\hline
\end{tabular}

The majority of respondents in this research are female. There were 102 female and 94 male respondents. This means that out of the 196 respondents, $52 \%$ were female respondents while the other remaining $48 \%$ were male respondents.

The majority of respondents were in the line of 31- 40 years old, which represented $49.5 \%$ or the frequency of 97 respondents, followed by 53 respondents who were $41-50$ years old $(27 \%)$, there were 26 respondents who were 20-30 years $(13.3 \%)$ and the respondents whom were above 50 years old had 20 people with $10.2 \%$ in the total.

When considered regarding the education level, most of the respondents $(51 \%)$ hold a bachelor's degree with the frequency of 100 respondents, while $38.3 \%$ or the frequency of 75 respondents hold master's degree, there were 16 respondents who graduated with doctoral degrees, which was equal to $8.2 \%$ and only $2.6 \%$ with the frequency of 5 respondents hold below a bachelor's degree.

Based on Table 4, out of the 196 respondents, 112 were married $(57.1 \%)$. Followed by 62 respondents in the percentage of $31.6 \%$ who were single and the remaining of respondents were divorced with the frequency of 22 respondents (11.2\%).

There were 92 respondents who had income from 2.000.0015.000 .000 LAK occupied by $46.9 \%$, and 59 respondents who had income from 5.000.001-10.000.000 LAK occupied by 30.1\%. The group of respondents which had income above 10.000.000 LAK was $17.3 \%$ with the 34 respondents, and only 11 respondents who had income below 2.000.000 LAK with 5.6\%.

From Table 6, the highest percentage of the respondents have been working for 6-10 years (which is 31.1\%) with 61 respondents, followed by the respondents who have been working for $1-5$ years which was $29.1 \%$ with the frequency of 57 respondents. The respondents who have been working for $11-15$ years is $18.4 \%$ with the frequency of 36 respondents. There are 15 respondents who have been working for 1620 years and above 20 years which is $7.7 \%$, and only 12 respondents who have been working for below 1 year with $6.1 \%$.

The second part: The analysis regarding the level of agreement in terms of job characteristics and work experience of employees of Lao Development Bank was analyzed by using basic statistics to find the mean $\bar{X}$ and standard deviation (S.D) with the interpretation based on criteria of. ${ }^{11}$ 
The analysis regarding the level of agreement in terms of job characteristics of employees of Lao Development Bank. The respondents of this study had 196 Mean $(\bar{X})$. Standard Deviation (S.D) was used as an analysis tool, which will be illustrated in the form of the Table 7 as follows:

The results from Table 7 showed that the mean $(\overline{\mathrm{X}})$ value, standard deviation (S.D) value, and the level of agreement in terms of job characteristics of employees of Lao Development Bank had strongly agreed from the overall picture $(\bar{X}=4.28$, S.D $=0.385)$ When each statement was considered by the mean $(\overline{\mathrm{X}})$ value of the three highest levels, such as the employees have a good understanding of their work ( $\bar{X}=4.82$, S.D $=0.457)$, followed by the employees' job characteristic have the opportunity to interact with both internal and external organization's individuals $(\overline{\mathrm{X}}=4.47$, S.D $=0.761)$, and employees have the expectation to be promoted $(\overline{\mathrm{X}}=4.23$, S.D $=$ $0.667)$ respectively.

Table 7 Demonstrates Mean ( $\bar{X}$ ) and Standard Deviation (S.D) of the level of agreement in terms of job characteristics of employees of Lao Development Bank

\begin{tabular}{llll}
\hline Job characteristics & N & Mean & Std. Deviation \\
\hline $\begin{array}{l}\text { l.You have a good understanding } \\
\text { of your work. }\end{array}$ & 196 & 4.82 & .457 \\
$\begin{array}{l}\text { 2.You feel that you have a freedom } 196 \\
\text { to work. }\end{array}$ & 4.10 & .502 \\
$\begin{array}{l}\text { 3.You think that your work is } \\
\text { diverse. }\end{array}$ & 196 & 3.96 & .933 \\
$\begin{array}{l}\text { 4.You think that your work is } \\
\text { challenging. }\end{array}$ & 196 & 4.12 & .668 \\
$\begin{array}{l}\text { 5.Your job characteristic has the } \\
\text { opportunity to interact with both } \\
\text { internal and external organization's } \\
\text { individuals. }\end{array}$ & 4.46 & .761 \\
$\begin{array}{l}\text { 6.You have an expectation to be } \\
\text { promoted. }\end{array}$ & 196 & 4.23 & .667 \\
\begin{tabular}{l} 
Total \\
\hline
\end{tabular} & 196 & 4.28 & .385 \\
\hline
\end{tabular}

The results from Table 8 found that the mean $(\overline{\mathrm{X}})$ value, standard deviation (S.D) value, and the level of agreement in terms of work experiences of employees of Lao Development Bank had agreed from the overall picture $(\bar{X}=4.19$, S.D $=0.408)$. When each statement was considered by the mean $(\overline{\mathrm{X}})$ value of the three highest levels, such as employees feel that they have a significant role in the organization $(\overline{\mathrm{X}}$ $=4.72, \mathrm{~S} . \mathrm{D}=0.512$ ), followed by the employees have a good attitude towards their colleagues in the organization. $(\bar{X}=4.30, S . D=0.781)$, and the employees have a good attitude towards the organization $(\overline{\mathrm{X}}$ $=4.27, \mathrm{~S} . \mathrm{D}=0.674$ ) respectively.

The third part: The analysis regarding the level of the organizational commitment of employees of Lao Development Bank was analyzed by using basic statistics to find the mean $(\overline{\mathrm{X}})$ and standard deviation (S.D) with the interpretation based on criteria of. ${ }^{11}$
Table 8 Demonstrates Mean ( $\bar{X}$ ) and Standard Deviation (S.D) of the level of agreement in terms of work experience of employees of Lao Development Bank

\begin{tabular}{llll}
\hline Work experiences & N & Mean & $\begin{array}{l}\text { Std. } \\
\text { Deviation }\end{array}$ \\
$\begin{array}{l}\text { I.You feel that you have a significant role } \\
\text { to organization. }\end{array}$ & 196 & 4.72 & .512 \\
$\begin{array}{l}\text { 2.You feel that the organization can } \\
\text { respond to your needs appropriately. }\end{array}$ & 196 & 3.98 & .603 \\
$\begin{array}{l}\text { 3.You have confidence and trust in the } \\
\text { organization. }\end{array}$ & 196 & 3.88 & .897 \\
$\begin{array}{l}\text { 4.You feel that this organization can rely } \\
\text { on }\end{array}$ & 196 & 4.05 & .732 \\
$\begin{array}{l}\text { 5. You have a good attitude towards your } \\
\text { colleagues in the organization. }\end{array}$ & 196 & 4.30 & .781 \\
$\begin{array}{l}\text { 6.You have a good attitude towards the } \\
\text { organization. }\end{array}$ & 196 & 4.27 & .674 \\
\begin{tabular}{l} 
Total \\
\hline
\end{tabular} & 196 & 4.19 & .408 \\
\hline
\end{tabular}

The analysis factors affecting organizational commitment of employees of Lao Development Bank. This research has 196 respondents. Mean $(\bar{X})$ and Standard Deviation (S.D) were used to as an analysis tool, which is illustrated in the form of (Tables 9-12) as follows:

The results from Table 9 showed that the mean $(\bar{X})$ value, standard deviation (S.D) value, and the level of factors affecting organizational commitment of employees of Lao Development Bank had agreed from the overall picture $(\bar{X}=4.17$, S.D $=0.324)$. When each aspect was considered by the mean $(\overline{\mathrm{X}})$ value of the three highest levels, such as continuance commitment $(\bar{X}=4.33$, S.D $=0.314)$, followed by normative commitment $(\bar{X}=4.10, S . D=0.340)$, and affective commitment ( $\bar{X}=4.09$, S.D $=0.319)$ respectively.

Table 9 Demonstrates Mean $(\bar{X})$ and Standard Deviation (S.D) of the level of factors affecting organizational commitment of employees of Lao Development Bank in the overall picture

\begin{tabular}{lccll}
\hline \multirow{2}{*}{$\begin{array}{l}\text { Organizational } \\
\text { Commitment }\end{array}$} & \multicolumn{4}{c}{ Level of commitment } \\
\cline { 2 - 5 } & $\overline{\mathrm{X}}$ & S.D & $\begin{array}{l}\text { Opinion } \\
\text { Level }\end{array}$ & Ranking \\
\hline $\begin{array}{l}\text { Affective } \\
\text { commitment }\end{array}$ & 4.09 & 0.319 & Agree & 3 \\
$\begin{array}{l}\text { Continuance } \\
\text { commitment }\end{array}$ & 4.33 & 0.314 & Strongly agree & I \\
$\begin{array}{l}\text { Normative } \\
\text { commitment }\end{array}$ & 4.10 & 0.340 & Agree & 2 \\
Total & 4.17 & 0.324 & Agree & \\
\hline
\end{tabular}

The results from Table 10 found that the mean $(\overline{\mathrm{X}})$ value, standard deviation (S.D) value, and the level of factors affecting organizational commitment of employees of Lao Development Bank in terms of affective commitment had agreed from the overall picture ( $\bar{X}=4.09$, $\mathrm{S} . \mathrm{D}=0.319)$. When each statement was considered by the mean $(\overline{\mathrm{X}})$ value of the three highest levels, such as the employees are proud to be part of the Lao Development Bank ( $\bar{X}=4.87$, S.D $=0.364)$, followed by the employees feel willing to cooperate with the organization 
without getting any irritation $(\overline{\mathrm{X}}=4.13$, S.D $=0.643$ ), and the employees feel that they are willing to devote to this organization ( $\overline{\mathrm{X}}=4.09$, S.D $=0.866$ ) respectively.

Table 10 Demonstrates Mean ( $\bar{X})$ and Standard Deviation (S.D) of the level of factors affecting organizational commitment of ss of Lao Development Bank in terms of affective commitment

\begin{tabular}{|c|c|c|c|}
\hline Affective commitment & $\mathbf{N}$ & Mean & $\begin{array}{l}\text { Std. } \\
\text { Deviation }\end{array}$ \\
\hline $\begin{array}{l}\text { I.You are proud to be part of the Lao } \\
\text { Development Bank. }\end{array}$ & 196 & 4.87 & .364 \\
\hline $\begin{array}{l}\text { 2. You feel that the problem of organization } \\
\text { like your own problem. }\end{array}$ & 196 & 3.96 & .520 \\
\hline $\begin{array}{l}\text { 3. You feel that your co-worker like your } \\
\text { family member. }\end{array}$ & 196 & 3.60 & .782 \\
\hline $\begin{array}{l}\text { 4. You feel that this organization like your } \\
\text { home. }\end{array}$ & 196 & 3.89 & .670 \\
\hline $\begin{array}{l}\text { 5. You feel that you are willing to devote to } \\
\text { this organization. }\end{array}$ & 196 & 4.09 & .866 \\
\hline $\begin{array}{l}\text { 6. You feel that you are willing to cooperate } \\
\text { with the organization without getting any } \\
\text { irritation. }\end{array}$ & 196 & 4.13 & .643 \\
\hline Total & 196 & 4.09 & .319 \\
\hline
\end{tabular}

The results from Table 11 indicated that the mean $(\overline{\mathrm{X}})$ value, standard deviation (S.D) value, and the level of factors affecting organizational commitment of employees of Lao Development Bank in terms of continuance commitment had strongly agreed from the overall picture $(\bar{X}=4.33$, S.D $=0.314)$. When each statement was considered by the mean $(\overline{\mathrm{X}})$ value of the three highest levels, such as the employees think that they would work with Lao Development Bank until retirement $(\bar{X}=4.86$, S.D $=0.379)$, followed by the difference in salary cannot make them decide to quit the job $(\overline{\mathrm{X}}=$ 4.39 , S.D $=0.719)$, and this organization can fulfill what they need sufficiently $(\bar{X}=4.21, S . D=0.710)$ respectively.

Table I I Demonstrates Mean ( $\bar{X}$ ) and Standard Deviation (S.D) of the level of factors affecting organizational commitment of employees of Lao Development Bank in terms of continuance commitment

\begin{tabular}{|c|c|c|c|}
\hline Continuance aspects & $\mathbf{N}$ & Mean & $\begin{array}{l}\text { Std. } \\
\text { Deviation }\end{array}$ \\
\hline $\begin{array}{l}\text { I.You would be living in hardship if you } \\
\text { decided to leave this organization }\end{array}$ & 196 & 4.19 & .704 \\
\hline $\begin{array}{l}\text { 2. This organization can fulfill what you need } \\
\text { sufficiently. }\end{array}$ & 196 & 4.21 & .710 \\
\hline $\begin{array}{l}\text { 3. You think that this organization can fulfill } \\
\text { what you need more than others. }\end{array}$ & 196 & 4.13 & .764 \\
\hline 4. You still need to work with Lao & & & \\
\hline $\begin{array}{l}\text { Development Bank because of receiving an } \\
\text { appropriate welfare and benefit. }\end{array}$ & 196 & 4.21 & .698 \\
\hline $\begin{array}{l}\text { 5. The difference in salary cannot make you } \\
\text { decide to quit the job. }\end{array}$ & 196 & 4.39 & .719 \\
\hline $\begin{array}{l}\text { 6. You think that you would work with Lao } \\
\text { Development Bank until retirement. }\end{array}$ & 196 & 4.86 & .379 \\
\hline Total & 196 & 4.33 & .314 \\
\hline
\end{tabular}

The results from Table 12 found that the mean $(\overline{\mathrm{X}})$ value, standard deviation (S.D) value, and the level of factors affecting organizational commitment of employees of Lao Development Bank in terms of normative commitment had agreed from the overall picture $(\overline{\mathrm{X}}=4.10$, S.D $=0.340)$. When each statement was considered by the mean $(\bar{X}$ ) value of the three highest levels, such as the employees are willing and always ready to reward this organization with everything for the development of the organization $(\bar{X}=4.51$, S.D $=0.636)$, followed by "although they got another offer for a better job elsewhere they would not feel" it was right to leave the organization ( $\bar{X}=4.34$, S.D $=$ 0.772 ), and they would feel guilty if they left this organization, while the organization is in trouble $(\bar{X}=4.11, S . D=0.627)$ respectively.

Table 12 Demonstrates Mean $(\bar{X})$ and Standard Deviation (S.D) of the level of factors affecting organizational commitment of employees of Lao Development Bank in terms of normative commitment

\begin{tabular}{|c|c|c|c|}
\hline Normative commitment & $\mathbf{N}$ & Mean & $\begin{array}{l}\text { Std. } \\
\text { Deviation }\end{array}$ \\
\hline $\begin{array}{l}\text { I.You do not think you would resign from } \\
\text { the organization right now because you have } \\
\text { an affiliation with your colleagues in this } \\
\text { organization. }\end{array}$ & 196 & 4.01 & .518 \\
\hline 2. This organization deserves your loyalty. & 196 & 3.60 & .833 \\
\hline $\begin{array}{l}\text { 3. You would feel guilty if you left this } \\
\text { organization, while the organization is in } \\
\text { trouble. }\end{array}$ & 196 & 4.11 & .627 \\
\hline $\begin{array}{l}\text { 4. "Although you got another offer for a } \\
\text { better job elsewhere you would not feel" it } \\
\text { was right to leave the organization. }\end{array}$ & 196 & 4.34 & .772 \\
\hline $\begin{array}{l}\text { 5. You never think to move to work with } \\
\text { your organization's competitor. }\end{array}$ & 196 & 4.08 & .704 \\
\hline $\begin{array}{l}\text { 6. You are willing and always ready to rewarc } \\
\text { this organization with everything for the } \\
\text { development of the organization. }\end{array}$ & d 196 & 4.51 & .636 \\
\hline Total & 196 & 4.10 & .340 \\
\hline
\end{tabular}

The fourth part presents the results of the hypothesis testing.

Hypothesis 1: The employees of Lao Development Bank with different personal factors have a different commitment to organization.

Hypothesis 1.1: A different gender will have a different commitment to organization.

$\mathbf{H}_{0}$ : A different gender will have the commitment to organization with no difference.

$\mathbf{H}_{1}$ : A different gender will have a different commitment to organization

The statistic used for data analysis is the independent t-test with significance level at 0.05 , if significance level less than 0.05 , it rejects $\mathrm{H}_{0}$.

Table 13 showed the results of data analysis from the employees of Lao Development Bank classified by gender. It was found that the overall picture of the level of organizational commitment of employees was no different between male and female employees with 
significance level at 0.05 , and when each aspect was considered, such as affective, continuance and normative commitment found that the level of the organizational commitment of employees, there was no difference between male and female with significance level at 0.05 .

Table 13 Compares the difference among mean of level of factors affecting organizational commitment of employees of Lao Development Bank classified by gender

\begin{tabular}{lllllll}
\hline \multirow{2}{*}{$\begin{array}{l}\text { Organizational } \\
\text { Commitment }\end{array}$} & \multicolumn{7}{l}{ t-test for Equality Mean } & & & \\
\cline { 2 - 7 } & Gender & $\bar{X}$ & S.D & t & df & Sig. \\
\hline Affective & Male & 4.08 & 0.3 & -0.172 & 194 & 0.86 \\
commitment & Female & 4.09 & 0.33 & & & \\
Continuance & Male & 4.35 & 0.25 & 1.113 & 179.93 & 0.26 \\
commitment & Female & 4.30 & 0.36 & & & \\
Normative & Male & 4.11 & 0.34 & 0.194 & 194 & 0.84 \\
commitment & Female & 4.10 & 0.34 & & & \\
& Male & 4.18 & 0.21 & 0.543 & 194 & 0.58 \\
Overall & Female & 4.16 & 0.22 & & & \\
\hline
\end{tabular}

In summary, the group of respondents who were female, there was a feeling of commitment to organization with no difference from male respondents.

The analysis comparing of the difference of the mean level of factors affecting organizational commitment of employees of Lao Development Bank classified by age, educational level, marital status, income per month and length of employment. F-test, one way ANOVA (Analysis of Variance) was used to examine the correlations among variable factors, and the multiple comparison of LSD test which was illustrated in the form of Table 14-19 as follows:
Hypothesis 1.2 A group of a different age will have a different commitment to organization.

$\mathbf{H}_{\mathbf{0}}$ : A group of a different age will have the commitment to organization with no difference.

$\mathbf{H}_{1}$ : A group of a different age will have a different commitment to organization.

The statistic used for data analysis is F-test (one way ANOVA) with significance level at 0.05 , if significance level less than 0.05 , it rejects $\mathrm{H}_{0}$.

Table 14 indicated that the results of data analysis from the employees of Lao Development Bank, classified by age, was found that the overall picture of the level of organizational commitment of employees among a group which has a different age, there was the level of the commitment to organization with no difference $(\mathrm{F}=2.613$, Sig. $=0.053$ ) with significance level at 0.05 . When each aspect was considered, such as affective commitment, continuance commitment and normative commitment, showed that the group which had a different age, there was the level of the commitment to organization with no difference with significance level at 0.05 .

In summary, the group of respondents, in terms of demographic information which has a different age, there was the commitment to organization with no difference.

Hypothesis 1.3 A group of a different education level will have a different commitment to organization.

H : A group of a different education level will have the commitment to ${ }^{0}$ organization with no difference.

$\mathbf{H}_{1}$ : A group of a different education level will have a different commitment to organization.

Table 14 Compares the difference among mean of the level of factors affecting organizational commitment of employees of Lao Development Bank classified by age

ANOVA

\begin{tabular}{|c|c|c|c|c|c|c|}
\hline & & Sum of Squares & df & Mean Square & $\mathbf{F}$ & Sig. \\
\hline & Between Groups & .537 & 3 & .179 & 1.771 & .154 \\
\hline \multirow[t]{3}{*}{ Affective commitment } & Within Groups & 19.423 & 192 & .101 & & \\
\hline & Total & $19.96 \mid$ & 195 & & & \\
\hline & Between Groups & .447 & 3 & .149 & 1.516 & .212 \\
\hline \multirow[t]{3}{*}{ Continuance commitment } & Within Groups & 18.859 & 192 & .098 & & \\
\hline & Total & 19.305 & 195 & & & \\
\hline & Between Groups & .520 & 3 & .173 & 1.505 & .215 \\
\hline \multirow[t]{3}{*}{ Normative commitment } & Within Groups & 22.098 & 192 & .115 & & \\
\hline & Total & 22.618 & 195 & & & \\
\hline & Between Groups & .364 & 3 & .121 & 2.613 & .053 \\
\hline \multirow[t]{2}{*}{ Overall } & Within Groups & 8.923 & 192 & .046 & & \\
\hline & Total & 9.287 & 195 & & & \\
\hline
\end{tabular}


Table 15 compares the difference among mean of the level of factors affecting organizational commitment of employees of Lao Development Bank classified by education level

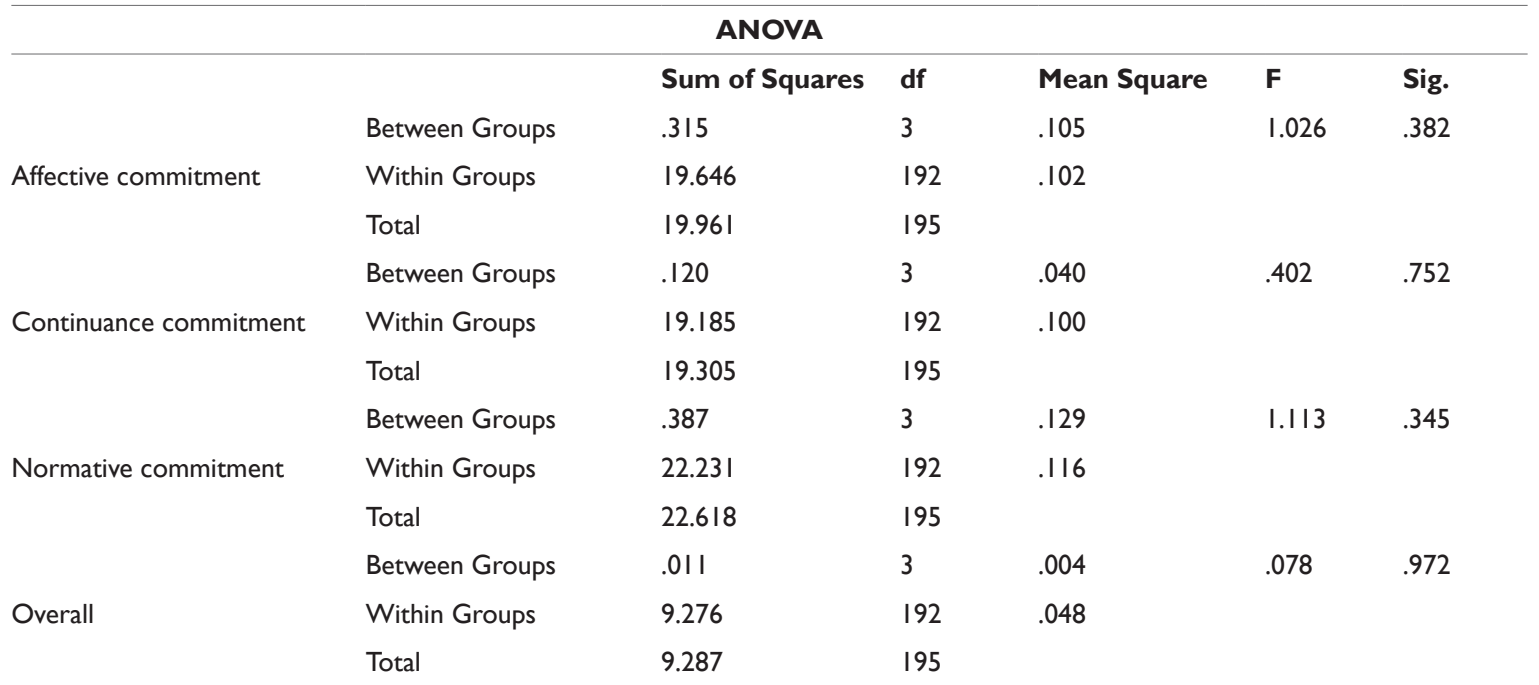

Table 16 Compares the difference among mean of the level of factors affecting organizational commitment of employees of Lao Development Bank classified by marital status

\begin{tabular}{|c|c|c|c|c|c|c|}
\hline \multicolumn{7}{|c|}{ ANOVA } \\
\hline & Between Groups & .107 & 2 & .054 & .521 & .595 \\
\hline \multirow[t]{2}{*}{ Affective commitment } & Within Groups & 19.854 & 193 & .103 & & \\
\hline & Total & 19.961 & 195 & & & \\
\hline \multirow{2}{*}{ Continuance commitment } & Total & 19.305 & 195 & & & \\
\hline & Between Groups & .001 & 2 & .001 & .006 & .994 \\
\hline \multirow[t]{2}{*}{ Normative commitment } & Within Groups & 22.617 & 193 & .117 & & \\
\hline & Total & 22.618 & 195 & & & \\
\hline Overall & Total & 9.287 & 195 & & & \\
\hline
\end{tabular}

Table 17 Compares the difference among mean of the level of factors affecting organizational commitment of employees of Lao Development Bank classified by income per month

\begin{tabular}{|c|c|c|c|c|c|c|}
\hline \multicolumn{7}{|c|}{ ANOVA } \\
\hline & & Sum of Squares & df & Mean Square & $\mathbf{F}$ & Sig. \\
\hline & Between Groups & .341 & 3 & .114 & 1.112 & .345 \\
\hline \multirow[t]{3}{*}{ Affective commitment } & Within Groups & 19.620 & 192 & .102 & & \\
\hline & Total & $19.96 \mid$ & 195 & & & \\
\hline & Between Groups & .117 & 3 & .039 & .389 & .761 \\
\hline \multirow[t]{3}{*}{ Continuance commitment } & Within Groups & 19.189 & 192 & .100 & & \\
\hline & Total & 19.305 & 195 & & & \\
\hline & Between Groups & .421 & 3 & .140 & 1.214 & .306 \\
\hline \multirow[t]{3}{*}{ Normative commitment } & Within Groups & 22.197 & 192 & .116 & & \\
\hline & Total & 22.618 & 195 & & & \\
\hline & Between Groups & .144 & 3 & .048 & 1.011 & .389 \\
\hline \multirow[t]{2}{*}{ Overall } & Within Groups & 9.143 & 192 & .048 & & \\
\hline & Total & 9.287 & 195 & & & \\
\hline
\end{tabular}


Table I 8 Compares the difference among mean of the level of factors affecting organizational commitment of employees of Lao Development Bank classified by length of employment

\begin{tabular}{|c|c|c|c|c|c|c|}
\hline \multicolumn{7}{|c|}{ ANOVA } \\
\hline & & Sum of Squares & df & Mean Square & $\mathbf{F}$ & Sig. \\
\hline & Between Groups & .617 & 5 & .123 & 1.213 & .305 \\
\hline \multirow[t]{3}{*}{ Affective commitment } & Within Groups & 19.343 & 190 & .102 & & \\
\hline & Total & $19.96 \mid$ & 195 & & & \\
\hline & Between Groups & 1.117 & 5 & .223 & 2.333 & .044 \\
\hline \multirow[t]{3}{*}{ Continuance commitment } & Within Groups & 18.189 & 190 & .096 & & \\
\hline & Total & 19.305 & 195 & & & \\
\hline & Between Groups & .413 & 5 & .083 & .707 & .619 \\
\hline \multirow[t]{3}{*}{ Normative commitment } & Within Groups & 22.205 & 190 & .117 & & \\
\hline & Total & 22.618 & 195 & & & \\
\hline & Between Groups & .302 & 5 & .060 & 1.279 & .274 \\
\hline \multirow[t]{2}{*}{ Overall } & Within Groups & 8.985 & 190 & .047 & & \\
\hline & Total & 9.287 & 195 & & & \\
\hline
\end{tabular}

Table 19 Compares mean in multiple comparison of the level of organizational commitment of employees of Lao Development Bank classified by length of employment

\begin{tabular}{|c|c|c|c|c|c|c|c|}
\hline Organizational commitment & & $\begin{array}{l}\text { Below I } \\
\text { year }\end{array}$ & $\mathrm{I}-5$ years & $\begin{array}{l}6-10 \\
\text { years }\end{array}$ & $\begin{array}{l}\text { I I-I5 } \\
\text { years }\end{array}$ & $\begin{array}{l}16-20 \\
\text { years }\end{array}$ & $\begin{array}{l}\text { Over } 20 \\
\text { years }\end{array}$ \\
\hline Continuance aspect & $\overline{\mathrm{X}}$ & 4.39 & 4.24 & 4.4 & 4.28 & 4.44 & 4.36 \\
\hline Below I year & 4.39 & - & 0.138 & 0.874 & 0.283 & 0.643 & 0.781 \\
\hline I-5 years & 4.24 & & - & $0.005^{*}$ & 0.595 & $0.026 *$ & 0.21 \\
\hline $6-10$ years & 4.40 & & & - & 0.053 & 0.654 & 0.585 \\
\hline II-I5 years & 4.28 & & & & - & 0.081 & $0.4 \mid 4$ \\
\hline $16-20$ years & 4.44 & & & & & - & 0.423 \\
\hline Above 20 years & 4.36 & & & & & & - \\
\hline
\end{tabular}

* Significance level at 0.05

The statistic used for data analysis is F-test (one way ANOVA) with significance level at 0.05 , if significance level less than 0.05 , it rejects $\mathrm{H}_{0}$.

Table 15 indicated that the results of data analysis from the employees of Lao Development Bank classified by educational level, was found that the overall picture of the level of organizational commitment of employees among a group which had a different educational level, there was the level of the commitment to organization with no difference $(\mathrm{F}=0.078$, Sig. $=0.972)$ with significance level at 0.05 . When each aspect was considered, such as affective, continuance and normative commitment, showed that the group of a different educational level, there was the level of the commitment to organization with no difference with significance level at 0.05 .
In summary, the group of respondents in terms of demographic information which has a different educational level, there was the commitment to organization with no difference.

Hypothesis 1.4 A group of a different marital status will have a different commitment to organization.

$\mathbf{H}_{\mathbf{0}}$ : A group of a different marital status will have the commitment to organization with no difference.

$\mathbf{H}_{\mathbf{1}}$ : A group of a different marital status will have a different commitment to organization.

The statistic used for data analysis is F-test (one way ANOVA) with significance level at 0.05 , if significance level less than 0.05 , it rejects $\mathrm{H}_{0}$. 
Table 16 indicated that the results of data analysis from the employees of Lao Development Bank classified by marital status, was found that the overall picture of the level of organizational commitment of employees among a group which has a different marital status, there was the level of the commitment to organization with no difference $(F=0.008$, Sig. $=0.992)$ with significance level at 0.05 . When each aspect was considered, such as affective, continuance and normative commitment showed that the group of a different marital status, there was the level of the commitment to organization with no difference with significance level at 0.05 .

In summary, the group of respondents in terms of demographic information which has a different marital status, there was the commitment to organization with no difference.

Hypothesis 1.5 A group of a different income per month will have a different commitment to organization.

$\mathbf{H}_{0}$ : A group of a different income per month will have the commitment to organization with no difference.

$\mathbf{H}_{\mathbf{1}}$ : A group of a different income per month will have a different commitment to organization.

The statistic used for data analysis is F-test (one way ANOVA) with significance level at 0.05 , if significance level less than 0.05 , it rejects $\mathrm{H}_{0}$.

Table 17 indicated that the results of data analysis from the employees of Lao Development Bank classified by the income per month, was found that the overall picture of the level of organizational commitment of employees among a group which has a different income per month, there was the level of the commitment to organization with no difference $(\mathrm{F}=1.011$, Sig. $=0.389)$ with significance level at 0.05 , and when each aspect was considered, such as affective, continuance and normative commitment showed that the group of a different income per month, there was the level of the commitment to organization with no difference with significance level at 0.05 .

In summary, the group of respondents in terms of demographic information which has a different income per month, there was the commitment to organization with no difference.

Hypothesis 1.6 A group of a different length of employment will have a different commitment to organization.

$\mathbf{H}_{\mathbf{0}}$ : A group of a different length of employment will have the commitment to organization with no difference.

$\mathbf{H}_{1}$ : A group of a different length of employment will have a different commitment to organization.

The statistic used for data analysis is F-test (one way ANOVA) with significance level at 0.05 , if significance level less than 0.05 , it rejects $\mathrm{H}_{0}$.

The findings of Table 18 indicated that the results of data analysis from the employees of Lao Development Bank classified by the length of employment was found that the overall picture of the level of organizational commitment of employees among a group which has a different length of employment, there is the level of the commitment to organization with no difference $(\mathrm{F}=1.279$, Sig. $=0.274)$ with significance level at 0.05 , and when each aspect was considered, such as affective, continuance and normative commitment showed that there was only continuance aspect of the group which had a different length of employment, there was a different level of commitment to organization $(\mathrm{F}=2.333$, Sig. $=0.044)$ with significance level at 0.05 . Thus, when found the difference in terms of continuance commitment, the researcher has continued conducting the multiple comparison among a group which had a different length of employment which included 6 groups such as a group of below 1 year, 1-5 year, 6-10 year, 11-15 year, 16-20 year and above 20 years as Table 19 above:

In summary, the group of respondents in terms of demographic information from the overall picture which had a different length of employment, there was the commitment to organization with no difference, but except in terms of continuance commitment, there was a different level of commitment to organization.

The results from Table 19 indicated that the multiple comparison of LSD test for the length of employment in terms of continuance commitment. When each pair was compared by mean, such as the group of below 1 year, 1-5 years, 6-10 years, 11-15 years, 16-20 years and above 20 years were found that the group of 1-5 year had a different level of commitment to organization from the group of 6-10 years and 16-20 years with significance level at 0.05.

Summary of result of Hypothesis 1 Testing: The employees of Lao Development Bank who has different personal factors will have a different commitment to organization. From the data analysis was found that the personal factors which affected organizational commitment, such as the factor in terms of the length of employment can be identified that the different length of employment had a different commitment to organization. For the factor related to the group of different age, gender, educational level, marital status and income per month had the commitment to organization with no difference.

The fifth part: The results of correlation between job characteristics and work experiences with organizational commitment used to find out relationship by correlation coefficient value (r) and to summarize the results of hypothesis 2: Job characteristics of the employees of the Lao Development Bank have a relationship with the organizational commitment, and hypothesis 3: work experiences of the employees of the Lao Development Bank have a relationship with the organizational commitment.

The analysis of the relationship between job characteristics and work experiences with organizational commitment had used formula of Pearson Product Moment Correlation Coefficient as Table 20 below:

Hypothesis 2: Job characteristics of the employees of the Lao Development Bank have a relationship with the organizational commitment.

$\mathbf{H}_{\mathbf{0}}$ : Job characteristics of the employees of the Lao Development Bank have a relationship with the organizational commitment.

$\mathbf{H}_{\mathbf{1}}$ : Job characteristics of the employees of the Lao Development Bank have no relationship with the organizational commitment.

Hypothesis 3: Work experiences of the employees of the Lao Development Bank have a relationship with the organizational commitment.

$\mathbf{H}_{\mathbf{0}}$ : Work experiences of the employees of the Lao Development Bank have a relationship with the organizational commitment. 
$\mathbf{H}_{1}$ : Work experiences of the employees of the Lao Development Bank have no relationship with the organizational commitment.

The statistic used to analyze the relationship by testing correlation coefficient value (r). if has the value approximately equal to 1 , there is a slightly high relationship with correlation is significant at the 0.01 .
Table 20 showed that the factors, such as both job characteristics and work experiences had a moderate level of correlation with organizational commitment with correlation is significant at the 0.01 . Which job characteristics had the positive relationship with organizational commitment with $(\mathrm{r}=0.334)$ and work experiences had the positive relationship with organizational commitment with $(\mathrm{r}=$ $0.306)$.

Table 20 Demonstrates correlation coefficient value between job characteristic and work experience with organizational commitment

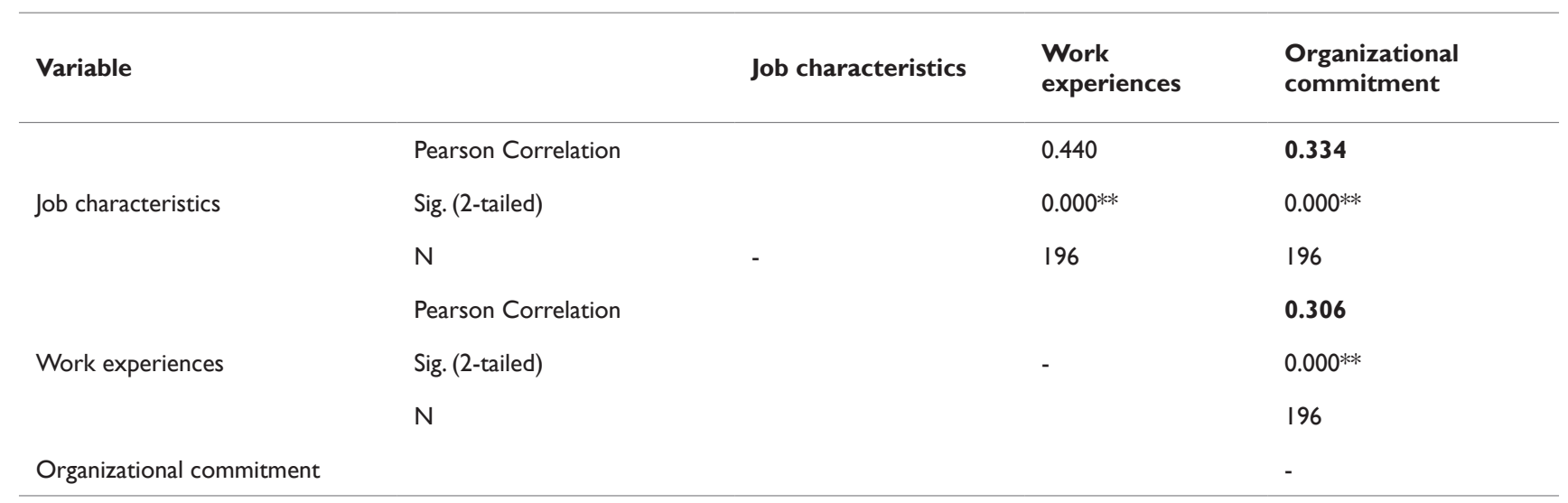

** Correlation is significant at the 0.01 level (2-tailed)

\section{Discussion and Conclusion}

From the study on factors affecting organizational commitment of employees of Lao Development Bank.

It has been concluded that the analysis concerning the level of organizational commitment of employees of Lao Development Bank found that the level of organizational commitment of employees was at high level from the overall picture, and the factors which enhanced employees to have the most feeling of commitment to organization, such as in terms of continuance commitment, the employees think that they would work with Lao Development Bank until retirement. Moreover, the difference in salary cannot make them decide to quit the job, and this organization can fulfill what they need sufficiently. For normative commitment, the employees are willing and always ready to reward this organization with everything for the development of the organization, "although they got another offer for a better job elsewhere they would not "feel" it was right to leave the organization, and they would feel guilty if they left this organization, while the organization is in trouble. In addition, in terms of affective commitment, the employees are proud to be part of Lao Development Bank. Furthermore, they are willing to cooperate with the organization without getting any irritation, and they feel that they are willing to devote to this organization. Which this finding was similar to ${ }^{12}$ the one that stated that the organizational commitment or loyalty refers to the willingness of the individuals which is one of the important factors in the organization.

In addition, comparing the level of the organizational commitment of employees of Lao Development Bank, there was no difference between male and female employees in affective, continuance and normative commitment. The group of different ages had the level of commitment to organization with no difference. Regarding the education level, marital status, and income per month, there was a level of commitment to the organization with no difference, but that was only in terms of continuance commitment of the group of employees which had a different length of employment, there was the different level of commitment to organization. Furthermore, when conducting multiple comparisons, the group with 1-5 years had a different level of commitment to organization than the group of employees with 6-10 years, and 16-20 years with significance level at 0.05.

Lastly, the analysis of the correlation between job characteristics and work experiences with organizational commitment of the employees of Lao Development Bank could find that job characteristics and work experiences of employees had the most significant relationship with organizational commitment.

\section{Recommedations}

From this study on factors affecting organizational commitment of employees of Lao Development Bank. There were some limitations found while carrying out research and there are some suggestions that researchers can recommend future researchers who are interested in this similar topic for the purpose of creating some enhancements to this study. Based on the results and conclusion of this study, the following recommendations are made for further work concerning this study and future research.

The further recommendations concerning this study are as follows: the organization should create a good attitude to employees in terms of affective commitment, such as enhancing the employees' morale to make them proud to be part of the Lao Development Bank. Furthermore, should try to retain the employees who are loyal and dedicated to the organization, because they think that they would work with Lao Development Bank until retirement, and moreover, the organization should strictly focus on and pay attention to the normative commitment, because they are willing and always ready to reward this organization with everything for the development of the 
organization.

The recommendations for future research, according to the population of this study was strictly restricted to only the employees in headquarters and the Vientiane capital branch of Lao Development Bank. Thus, the results of this study may not be applicable to other organizations, or those of various and different businesses. Regarding any further research, the future researchers may consider increasing the sample of the population, related factors and especially for position. Position may be one of the factors which has an effect on organizational commitment. As well as the research area, in order to achieve broader outcomes and real circumstances.

In addition, regarding the questionnaires, some respondents did not provide recommendations. Thus, the study might lack some additional important and interesting concepts regarding how to improve the commitment level within the organization. In the next research, regarding the ways of collecting information, research could be done by employing multiple methods, such as observation and direct interviewing as the tool, rather than using only questionnaires. This will benefit the study by acquiring greater and deeper information.

Lastly, regarding the above-mentioned recommendations, the researcher has expected that, this study would be able to be useful to future studies in the related field.

\section{References}

1. Lee CC, Chen CJ. The relationship between Employee Commitment and Job Attitude and It Effect on Service Quality in the Tourism Industry. American Journal of Industry and Business Management. 2013;3(1):196-208.

2. Bai J, Liu JP. A study on the Influence of Career Growth on Work
Engagement among New Generation Employees. Open Journal of Business and Management. 2018;6(1): 300-317.

3. Mullins LT. Management and Organizational Behavior. $5^{\text {th }}$ Edition, Financial Times Management, London. 1999.

4. Osei EA, Acquaah E, Acheampong P. Relationship between Organizational Commitment and Demographic Variables: Evidence from a Commercial Bank in Ghana. American Journal of Industry and Business Management. 2005;5(1):769-778.

5. Satoh M, Watanabe I, Asakura K. Factors Related to Affective Occupational Commitment among Japanese Nurse. Open Journal of Nursing. 2017;7(1):449-462.

6. Aghdasi S, Kiamanesh RA, Ebrahim NA. Emotional Intelligence and Organizational Commitment: Testing the Mediatory Role Occupational Stress and Job Satisfaction. Social and Behavioral Sciences. 2011;29(1):1965-1976.

7. Siu O. Job Stress and Job Performance among Employees in Hong Kong: The role of Chinese Work Values and Organizational Commitment. International Journal of Psychology. 2003;39(1):337-347.

8. Allen NJ, Meyer JP. The Measurement and Antecedents of Affective, Continuance, and Normative Commitment to the Organization. Journal of Occupational Psychology. 1990;63(1):1-18.

9. Cohen A. Multiple Commitments in the workplace: An integrative approach. Mahwah, NJ: Eribaum. 2003.

10. Steers RM. Antecedents and outcomes of organizational commitment. Administrative Science Quarterly. 1977;22(1):46-56.

11. Best, John W. Research in Education. $3^{\text {rd }}$ ed. Englewood Cliffs, New Jersey: Prentice. Hall Inc. 1977.

12. Barnard C. The Functions of the executive. Cambridge, Massachusetts: Harvard University. 1938. 